\title{
Attilâ İlhan'ın Şiirinde Bir Poetik “Geçiş” Örneği Olarak “i̇ş Başı” Şiiri
}

\author{
ARŞ. GÖR. MUSTAFA TEMIZSU*
}

Öz

Attilâ İlhan, Cumhuriyet dönemi Türk şiirinin önemli isimlerinden biridir. Genel bir ifadeyle şairin poetik serüveninin üç ana evreden oluştuğunu söylemek mümkündür. Bunlar, toplumcu gerçekçi şiir anlayışı, bireyin kendi varlığını ve evrendeki yerini sorguladığı evre ve son olarak neoklasik dönem olarak sıralanabilir. Şairin yayımlanan ilk şiir kitabı olan Duvar (1948), bu üç ana evre içerisindeki toplumcu gerçekçi dönemin örneklerinden biri olarak kaleme alınmıştır. Duvar'da yer alan "İş Başı" adlı şiir ise ilk bakışta toplumcu gerçekçi sanat anlayışının bir ürünü olarak görülmesine rağmen şairin ilerleyen dönemlerde geliştireceği poetikasına dair çeşitli izler taşır. Bu yazıda "İş Başı" şiiri, Attilâ İlhan'ın poetikasında gözlemlenen "geçiş" durumunu göstermesi açısından incelenecektir.

Anahtar sözcükler: Attilâ İlhan, “İş Başı”, Modern Türk Şiiri, Poetika, Şiir

\section{THE POEM “IŞ BAŞI” AS AN EXAMPLE OF POETIC “TRANSITION” IN ATTİLÂ İLHAN'S POETRY}

\section{Abstract}

Attilâ İlhan is one of the important names of Turkish poetry in the Republican period. In general terms, it is possible to say that the poetic adventure of the poet consists of three main phases. These can be listed as socialist realistic understanding of poetry, the stage in which an individual question his own existence and place in the universe, and finally the neoclassical period. Duvar (1948), his first published poetry book, was written as one of the examples of socialist realistic period in these three main phases. The poem "İş Başı" in Duvar, although seen as a product of the socialist realistic understanding of art at first glance, carries various traces of the poetics that the poet will develop in later periods. In this article, poem "İş Başı" will be examined in terms of showing the "transition" situation observed in Attilâ İlhan's poetics.

Keywords: Attilâ İlhan, "İş Baş1”, Modern Turkish Poetry, Poetics, Poetry

\footnotetext{
* İzmir K. Çelebi Ün. Sos. ve Beş. Bil. Fak. TDE Bölümü, mustafatemizsu@gmail.com, orcid.org/0000-0003-0539-4988 Gönderim tarihi: 11-11-2019 Kabul tarihi: 28-12-2019
} 


\section{Gíkiş}

7 Пürk şiirinin önemli isimlerinden biri olan Attilâ illhan hem poetik görüşleri hem de ortaya koyduğu şiirleri itibarıla Cumhuriyet dönemi edebiyat _ dünyasında dikkate değer bir yer edinmiştir. Şair, özellikle 1940'lı yıllarda poetik bir yaklaşım olarak karşımıza çıkan toplumcu gerçekçi şiir anlayışına bağlanarak sanatının temellerini atmıştır. Dolayısıyla ilk olarak, Attilâ İlhan'ın içinde bulunduğu şiir havzası ve bu havzanın Türk şiiri kanonu içindeki yeri ve konumu üzerinde durmak gerekir. Böylelikle ortaya atacağımız tezler aracllığıyla, şiirdeki teorik düzlemden pratik düzleme geçişe ve bu geçişin İlhan'ın poetikasındaki etkilerine işaret etmek mümkün olacaktır.

Ramazan Korkmaz, Attilâ İlhan'ın şiir serüveninin temelde üç ana eksen üzerine inşa edildiğini belirtmiştir. Bunlar, toplumcu gerçekçi evre (1941-1955); bireyin kendi varlığını ve evrendeki yerini sorguladığı evre (1959-1968) ve son olarak neoklasik dönem olarak adlandırılmıştır. Toplumcu gerçekçi evrede ses yapısı, içerik ve imge düzeni bakımından Attilâ İlhan şiirinin en önemli kaynaklarından biri Nazım Hikmet'in şiiridir. Eserlerini 1941 yılından itibaren toplumcu gerçekçi sanat anlayışı içinde ortaya koymaya başlayan Attilâ İlhan, ayn zamanda halk şiirinden de büyük oranda beslenmiştir. Savaşlar, özgürlük sorunları, toplumlardaki sömürü düzenleri ve insan sevgisi, bu dönem şiirlerinin ana izleklerini oluşturmaktadır (Korkmaz, 2007, s. 256). "Attilâ İlhan hem olağan dışı kent resimleriyle hem de sıra dışı karakterleriyle elde ettiği gerilimi şiir estetiğinin bir parçası hâline getirmiştir. $\mathrm{Bu}$ iki özelliğin yanı sıra onun şiirindeki takip edilme paranoyası, tutuklanma kaygisı ve siyasal baskılar da gerilim estetiğine hizmet eden ayrıntılardır." (Yivli, 2019, s. 300)

Modern Türk şiirinde toplumcu gerçekçi şiir, sanatsal endişeleri çoğunlukla materyalist dünya görüşü üzerine temellenen ve daha sonra Marksist ideolojiye bağlı bir estetik kuran şairlerin ortaya koyduğu bir poetik yaklaşımı ifade eder. Bu yaklaşımın pragmatik bir yönü ve "tezli" bir yapısı vardır. İnsanı belirleyen en temel öge kolektivizmdir. Yaşamın yegâne ereği, yeryüzündeki yaşama edimidir. Bu yönüyle toplumcu gerçekçi şiirler, içerik bakımından "eylemsel" bir yapı gösterir. Ayrıca sosyalist bireyselliğin geliştirilmesinin bu yaklaşımın temel amacı olduğunu söylemek mümkündür (Kahraman, 2000, s. 51).

Attilâ İlhan toplumcu gerçekçiliği, "doğru bir tarih şuuru içinde, toplumca batıll, gerçekçi, aydınlık bir estetik üzerine oturtulmuş, milli bir sanat kurma çabası taşıyan bir yöntem, bir görüş açısı olarak tanımlar" (İlhan, 2004, s.74). Burada dikkat çeken husus, şairin kullandığı estetik kavramına yüklediği anlamla ilgilidir. Çünkü poetikasındaki ilerleyen evreleri de göz önünde bulundurursak -henüz şiirin başında olmasına rağmen- İlhan için 
toplumcu gerçekçiliğin mahiyetinin hem ideolojik hem de estetik unsurlara dayalı bir yapıda olduğunu rahatlıkla söyleyebiliriz.

Ramazan Korkmaz, şairin poetikasını oluşturan ikinci ana evrenin özelliklerini belirlemek açısından şunları söylemiştir:

\begin{abstract}
“Attilâ İlhan'ın poetikasındaki ikinci evre olan bireyin kendi varlığını ve evrendeki yerini sorguladığı evrede, kent olgusunun modernleşme bağlamında doğurduğu çoğulcu ve paradoksal yaşam tarzının en karmaşık yapılarını görmek mümkündür. Burada modern dünya karşısında yalnız kalan ve varlı̆̆ı tehdit altında olan insanın şiirini yazar. Kent yaşamının biçimlendirdiği argo, küfür, bıçkınca konuşmalar, tarihsel dönem sapmaları gibi modernist dilsel ürünler, daha çok bu evrede görülen özelliklerdir" (Korkmaz, 2007, s. 257)
\end{abstract}

İlhan'ın poetikasındaki üçüncü evre ise neoklasik dönem olarak adlandırılmaktadır. Burada, özellikle 1965 'ten sonra İlhan'ın şiirinde tarihin yeniden yorumlanması, ben'in kendi kendisiyle hesaplaşması, tabiat ve kâinatla ilgili düşünceleri gibi hususlar gözlemlenmektedir (Çelik, 2007, s.30).

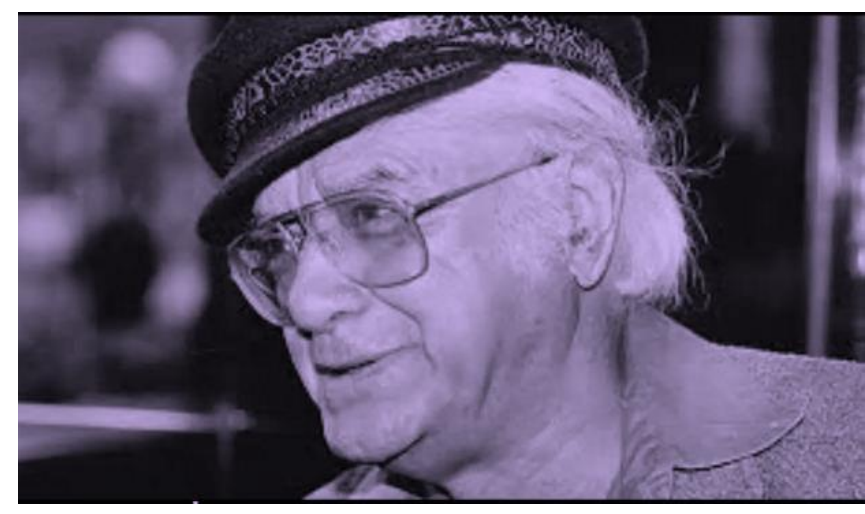

Attilâ İlhan Bunun bir sonucu olarak şairin Divan şiiri ile tanışarak onun ses ve imge dünyasından beslenmesi, Attilâ İlhan şiirinin çok boyutlu bir özellik kazanmasını sağlar. Daha önceki poetik deneyimlerini kendi şiir kimliğini tamamen değiştirmeden içselleştiren şair, gelenekle gelecek arasında örnek bir köprü görevi üstlenir (Korkmaz, 2007, s. 258).

Duvar, Türk şiiri incelemelerinin hemen hepsinde Attilâ İlhan'ın toplumcu gerçekçi şiir anlayışına dayalı olarak yayımladığı ilk şiir kitabı olarak değerlendirilir. Nitekim kitabın önsözünde Attilâ İlhan da "şair mademki kalabalık yaşıyor, mademki herkestir; zulmün, haksızlığın ve kör diktanın krallık ettiği o karanlık günlerde elbette hürriyetin, hakkın ve demokrasinin şarkılarını söylemeye savaşacaktır. Söylemiş işte." (Illhan, 2008, s. 9) sözleriyle bu durumu kabul eder görünmektedir. Sonuçta hem Attilâ İlhan'ın Duvar hakkındaki bu sözleri hem de edebiyat tarihi ve şiir inceleme çalışmaları temelde aynı duruma vurgu yapar. Buna göre şairin toplumcu gerçekçi poetik görüşü, pratik düzlemde Duvar'daki şiirlerine doğrudan yansımıştır. Attilâ İlhan'ın şiir paradigmasının ana hatlarının belirlenmesi açısından bu tespitler şüphesiz önem arz etmektedir. Ancak edebiyat tarihi incelemeleri ve eleştiri yöntemleri, yapısal özellikleri gereği tanımlama, kategorileştirme ve tasnif etme gibi ölçütleri temel hareket noktaları olarak belirlemektedir. Bu belirlemeler, zamanla kronik ve kanonik bir yapı kazanarak çoğunlukla söz konusu edebi dönem, süreç ya da ürünler 
hakkında dikkate değer bilgiler vermekle birlikte, kimi zaman edebi metinlerin kendine içkin estetik değerlerini yansıtma konusunda yetersiz kalır, kimi zamansa yanlış tespit ya da değerlendirmeler yapılmasına ve bunların zamanla tekrarlanmasına neden olur. Bütün bunların diyalektik olarak, bir yönüyle sosyal bilimlerin işleyiş mantığı için gerekli süreçler olduğunu kabul etmekle birlikte, diğer yandan bu kabulün, edebi eserlerin yeni bakış açılarıyla, yeniden incelenmeleri gerekliliğini doğurduğunu göz önünde bulundurmak gerekir.

Bütün bu tespitlerin ardından üzerinde durulması gereken bir diğer konu, toplumcu gerçekçi estetik anlayışının edebiyat tarihi içerisinde "tartışmalı" bir gündem maddesi olduğu gerçeğidir. Attilâ İlhan, Ercüment Behzat Lav, İlhami Bekir Tez, Cahit Irgat, Rıfat Ilgaz, Ahmet Arif, A. Kadir, Enver Gökçe, Niyazi Akıncıoğlu, Ömer Faruk Toprak gibi birçok şairin toplumcu gerçekçi şiirin başat isimlerinden olan Nazım Hikmet'in açtığı yoldan ilerleyerek bu poetik yaklaşıma bağlandığını söylemek mümkündür. Ancak hem o dönemin şairleri arasında hem de edebiyat tarihi araştırmaları içerisinde sıklıkla ele alınan konulardan biri, toplumcu gerçekçi şairlerin salt ideolojik kaygılardan hareketle şiirlerini oluşturdukları ve buna bağlı olarak, tekrara ve taklide dayalı "yavan" ve "güdümlü" bir şiire evrildikleri yönündeki tartışmalardır. Attilâ İlhan şiiri ise genel kanının aksine, poetikanın salt ideolojik çerçeve içerisine alınmadığı, şiirin aynı zamanda estetik unsurlarıyla ele alındığı bir yaklaşımı yansıtır.

Bu durumu sağlayan temel nedenlerden biri de şüphesiz Attilâ İlhan'ın özgün bir şair olma endişesidir. Her şeyden önce o, estetik planı öncelemesiyle Nazım Hikmet ve diğer toplumcu gerçekçi şairlerin oratoryoya dönüşen şiir anlayışlarından kaçınır. Kısacası toplumcu gerçekçi hareketin içinde kalmasına rağmen, Nazım Hikmet'in sesinin dışına çıkmasını başarabilmiş ender şairlerden birisidir (Korkmaz, 2007, s. 257). Nitekim şairin kendisi de bu duruma Duvar hakkındaki, “duvar dönemi şiirleri, öyle sanıyorum ki, asıl bu ve bundan sonraki şiirler sayılmalıdır. Kitabı çıkardığım sırada bu sesi ve içlemi yakalamıştım. Sürdürüyordum. Gariptir, ben dahil o tarihte hepimiz bu şiirlerde Nâzım'ın büyük etkisi olduğunu sanırdık. Şimdi bakıyorum da basbayağı Attilâ ilhan şiiri buluyorum onları, acaba yanılıyor muyum? bu elbet Nâzım'a olan büyük borcumu yadsımam anlamını taşımıyor, sadece etkinin kapsamı ya da derinliği bakımından bir soru." (İlhan, 2008, s. 181182) sözleriyle açıkça işaret etmektedir.

Sonuç olarak bütün değerlendirmelerin 1şığında ortaya atmamız gereken husus, şairin toplumcu gerçekçi şiir oratoryosu içinde nasıl özgün bir ses olarak karşımıza çıktığı ve bu durumun Attilâ İlhan'ın şiirine hangi yönleriyle yansıdığı sorusudur. Söz konusu probleme "İş Başı" şiiri bağlamında poetik ve estetik kaygı açısından baktığımızda ortaya çıkan yanıtlardan birinin, genel bir ifadeyle söyleyecek olursak şairin poetikasındaki "geçiş" 
durumuyla ilişkili olduğunu söylememiz mümkündür. Burada geçiş kavramından kast edilen -Attilâ İlhan'ın şairliği ana hatlarıyla çeşitli evrelerden oluşsa da- onun şiirindeki poetik evrelerin esasında iç içe olma eğilimi gösterdiği ve iç içe olma hâlinin bazı şiirlerde gözlemlenebilir nitelikte olduğu gerçeğidir. Bir örnek olması açısından bu yazıda "İş Başı" şiiri, toplumcu gerçekçi şiir anlayışının özelliklerinin şiirde ne ölçüde karşılık bulduğu sorunsalına bağlı olarak metin merkezli bir şekilde ele alınacaktır. Hemen genel bir ifadeyle söyleyecek olursak şiir hem içerik hem de yapı bakımından salt toplumcu gerçekçi bir poetikaya dayanmayan aynı zamanda metnin estetik düzleminin ele alındığı bir şiirdir. Bir yönüyle yukarıda sözü edilen Attilâ İlhan'ın sanatındaki kategorileştirmelere uygun, fakat başka bir yönüyle bu kategorileri aşan ve kendinden sonra gelecek olan poetik evrenin “öncüsü" niteliğinde olduğu dahi söylenebilir. Elbette bu durumu şairin diğer şiirlerinde de gözlemlemek mümkündür. Ancak burada "İş Başı"nı dikkate değer kılan, sözü edilen poetik geçişin şiirin içerik, tema ve söylem özelliklerinde gözlemlenebilir olmasıdır.

\section{POETIKK GEÇİŞIN TERAZİSI VE “İŞ BAŞI” Şİİİ}

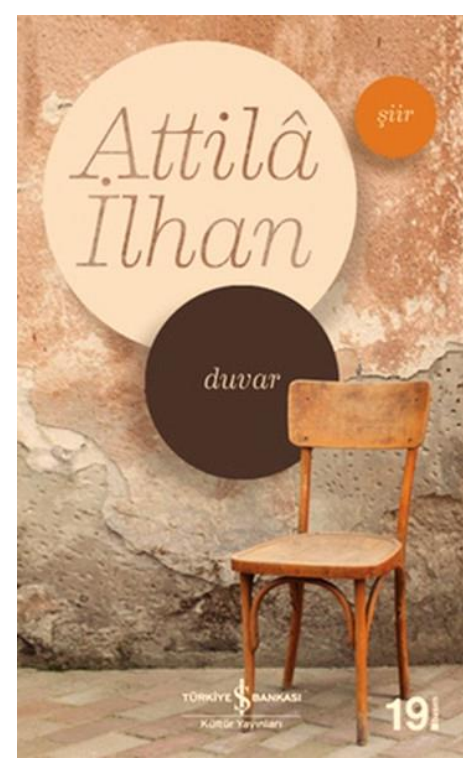

Attilâ İlhan Duvar1 için yazdığ1 önsözde, "duvar'daki şiirler yazıldığı sıralarda, günlük ve ömürlük yaşantımızın problemlerini, hemen daima hürriyet ve saadet ideallerinin ışığı altında ele alıyor; toplumcu bir gerçekçiliğin yanı sıra, bir de gelecek iyi günlerin iyimser romantisme'ini yapıyordu" (İlhan, 2008, s.12) diyerek poetikasının genel çerçevesini belirlemek ister. Burada dikkat edilmesi gereken husus, şairin yukarıda bahsetmiş olduğumuz toplumcu gerçekçi şiir anlayışına paralel özellikleri vurgulamasının yanı sıra, şiirinde yer aldığını düşündüğü “iyimser romantisme”dir. Dolayısıyla Attilâ İlhan'ın poetikasında, toplumcu gerçekçi sanatçlların estetik kaygılarında bulunan "güdümlü" sanat anlayışı yönündeki genel kabulün aksine, poetik bir "esneklik" söz konusudur. Sözünü ettiğimiz bu esneklik, aynı zamanda şiirlerindeki estetik yönelimlerle de koşutluk göstermektedir.

"İş Başı" şiiri birinci bölümü on dize, ikinci bölüm on beş dize olan iki ana bölümden oluşmaktadır. İki bölüm, şiirin hem içerik hem de dil ve üslup özellikleri açısından kimi zaman birbiriyle ilişkili, kimi zamansa birbirinden bağımsız özellikler gösterir. Dolayısıyla "İş Başı" bir bakıma, aşağıda detaylı olarak vurgulanacağı üzere, bir "gel-git" şiiridir. Bunun ilk örneği, anlam boyutunun kapısının aralandığı şiirin isimlendirilme aşamasında kendini

\footnotetext{
${ }^{1}$ Şiirden yapılacak olan alıntılar şu baskıya aittir: İlhan, Attilâ (2008). Duvar. İstanbul: Türkiye İş Bankası Kültür Yayınları.
} 
gösterir. Okurun edebi metnin anlam evrenine, ilk olarak ona verilen ad aracılığıyla adım attığ1 gerçeğinden hareketle, "İş Başı" şiirinin başlı̆̆ı, üzerine inşa edilen yapı ve içerik açısından önem ifade etmektedir. İlk bakışta bir insanın iş yapma edimi, kişinin iş ve emekle olan ilişkisinin toplumcu bir bakış açısıyla sunulacağı izlenimi, esasında toplumcu gerçekçi şiir görüşünün "birikimiyle" yakından ilgilidir. Ancak içerik incelememizin devamında da görüleceği üzere, şiir salt bu yöndeki bir yaklaşımı yansıtmaz. Dolayısıyla ilk elden söylenmesi gereken, “İş Başı”ndaki içeriğin yapısıyla seçilen isim arasında, şiirin tamamındaki poetik kaygı açısından birtakım farklılıkların bulunduğu gerçeğidir.

"İş Başı", "kardeşim müşterek söylenir bir şarkımız vardır." dizesiyle başlar ve şiirdeki, "kardeşim" ifadesinin toplumcu gerçekçi şiir anlayışının kolektivist yaklaşımının şiirsel bir karşılığı olduğunu söylemek mümkündür. Bunun yanında, şiir öznesinin birinci teklik şahıs yapılı söyleminin yanı sıra, aynı zamanda "biz"e dair bir seslenişi söz konusudur. Burada "biz" ile kast edilen, ortak bir kader anlayışına sahip insanlar topluluğudur. Dolayısıyla, bir bakıma şiirin hem "failleri" hem de muhatapları kast edilen "biz"dir. Aynı dizedeki "müşterek söylenen şarkı" ifadesiyle sözünü ettiğimiz biz olma durumu pekiştirilir ve okurun zihninde bu şarkının ne olduğuna dair bir soru işareti oluşturulur. İlk bakışta, müşterek söylenen şarkının 1940'lı yılların emekçi sınıfının "acıklı" bir şarkısı olacağı düşünülebilir. Oysaki söz konusu şarkı, "sevinç gibi pırıl pırıl ümit gibi engin"dir. Burada seçilen şarkının anlam boyutu şiirin teması için önem arz etmektedir. Çünkü tematik ve estetik olarak içeriğin buradan itibaren "gel-git" eksenli bir boyut kazanmaya başladığını söylemek yanlış olmayacaktır. Bu durum ise temelde, şiirin terazisinin bir yönünde toplumcu gerçekçi şiir anlayışının, diğer yönünde ise aşk izleğinin etki alanlarının yer alması aracılığıyla sağlanır. Böylelikle içerik düzlemi, iki uç arasındaki dinamik ilişkiye bağlı olarak şekillenir.

Şiirin devamında sözü edilen şarkının, şiir öznesi ve onun "kardeşleri” için "zahmetsiz", "kolay hatırlanan" bir şarkı olduğu vurgusu yapılır. Sonraki dizede ise bu şarkının bir sözü, tırnak içine alınarak şiirin bir dizesi haline getirilir. Böylelikle, "kara deryalara doğan bir güneş gibisin", dizesiyle şiirle şarkı arasında bir paralellik kurulur. Bir bakıma "şiir içinde şiir" formu oluşturulmak suretiyle ikili bir içerik düzlemi yaratılır. Dolayısıyla ikili içerik düzlemi, ilkin bu dizeyle oluşturulur. Bunlardan ilki toplumcu gerçekçi poetikanın anlam düzlemini, diğeri ise şiir öznesinin kendi "ben"iyle ilgili olan anlam boyutunu oluşturur. İşte temelde bu iki yapı üzerine inşa edilen “İş Başı"nın estetik özellikleri, yine bu iki yapı arasındaki "gel-git hâli"nde kendini gösterir. Örneğin kara deryalara doğan güneş ifadesi, içerik itibarıyla bir umut ve yaşama sevinci izlenimi yaratır. Yine bu noktada toplumcu gerçekçi şiir anlayışını aşan, tematik olarak çeşitlilik gösteren bir yapı söz konusudur. Çünkü burada güneş, şiirde yaratılan öznel duyguların yansıtılması 
açısından nesneleştirilir. Bu bağlamda denilebilir ki "güneşi zapt eden" toplumcu gerçekçi şiirin karşısında, bu kez "güneşi bekleyen ve onunla temaşa eden" bir şiir öznesi söz konusudur.

“İş Başı"nın birinci bölümündeki "soframızda şarap, peynir ekmek ve üzüm”, dizesi şiir öznesinin ve onun merkezinde yansıtılan insan tipinin yaşayış biçimini ve sınıfsal yapısını göstermesi bakımından dikkat çekicidir. Ancak bu dizenin hemen ardından gelen ölülerin mezarda, tanrının semada unutulması fikri, sözünü ettiğimiz şarkının şiir öznesinde yarattığı mutluluğu ve hayatın acı gerçeklerinden kaçış hâlini yansıtır. Burada aynı zamanda toplumcu geçekçi şiir anlayışının önemli özelliklerinden biri olan materyalist dünya görüşünün etkisi de söz konusudur. Ancak bu görüşün aktarılış biçimi, ideolojik bir amacın ispat çabasından ziyade estetik bir özellik gösterir. Nitekim birinci bölümün sonu, bu düşünüş biçimini destekleyerek "dünya günlük güneşlik insanlar sanki mesuttur", dizesiyle tamamlanir.

“İş Başı”nın ikinci bölümü, bir tezat durumuyla başlar. Burada yukarıda bahsedilen gel-git durumunun gözle görülür bir etkisi söz konusudur. Bu bölümün ilk dizesi, daha önce sözünü ettiğimiz toplumcu gerçekçi şiir anlayışı etrafında gelişen tartışmalar için şiir aracılığıyla verilmiş bir yanıt gibidir. "niçin sade acıdan bahsetsin misralarım." dizesiyle başlayan bölümde, ilk bölümde yaratılan etki alanının başka bir yöne çekilmesi ve hissettirilen duygular açısından önemli bir farklılık gözlemlenmektedir. Çünkü dize, toplumcu gerçekçi şiir karşısında estetik endişelere dayalı bir düşünceyi imler ve esasında "karşıt" bir poetikayı ifade eder. Dolayısıyla şiirin birinci bölümüyle ikinci bölümü arasındaki geçişte, bir bakıma "artı-eksi" kutuplu bir ilişki söz konusudur ve iki kutup arasında hem tematik hem de üslup özellikleri açısından bir gel-git durumu oluşturulur. $\mathrm{Bu}$ durumu yansıtması açısından, bir sonraki dizede şiirin konusunun şiir yazma ediminin kendisine doğru evrilmesi önemlidir. Çünkü şiir öznesi, “ben de bilirim aşk için şiir yazmasını" ifadeleriyle, belki de kendi varoluşunun bir sonucu olarak, şiiri aşk izleğinin yarattığı anlam dünyasının içine doğru çeker. Bu bağlamda şiirde, toplumcu gerçekçi poetikanın etkisiyle toplumsal sorunlar içerisinde kolektif bir endişeyle konu edilen insanın karşısında, bu kez kendi iç dünyasındaki bireysel özellikleriyle var olan başka bir insan tipi ortaya çıkar. Bunun bir sonucu olarak da şu iki dize önemlidir:

"kalbim pürheves rüzgârda perişan saçlarım

kusura bakılmaz neyleyim ahval-i sevdadı"

Bu iki dizeyle, şiirin birinci bölümünde yaratılan duygu dünyasının dışında, şiir öznesinin duyguları aşk izleğinin yarattı̆̆ı imajlar aracılığıyla ortaya koyulur. Âşık olma durumunun "kusura bakmak" deyimiyle aktarılması ise hem şiir öznesinin "utanma" hâlini hem de özne ile toplum arasındaki iç çatışmaları yansıtmaktadır. Çünkü toplumcu gerçekçi 
poetikanın düşünsel birikimiyle, aşk ve âşık olma hâli karşı karşıya gelir. Dolayısıyla burada da terazinin iki ucuna yönelik bir söylem söz konusudur.

Sözünü ettiğimiz aşk izleğinin yarattı̆̆ anlam dünyasının bir sonucu olarak, şiirin sonraki dizesinde ikinci bir öznenin varlığı dikkati çekmektedir. Bu kişi, şiir öznesinin "gözleri menevişli" sevgilisidir. Bu noktada da bir gel-git hâli söz konusudur. Çünkü sevgili sözünü ettiğimiz iç çatışmaya bağlı olarak yansıtılır. O, romantik izlenim ve duyumsamalar açısından sunulmaz. İç çatışmadan kaçışın bir göstergesi olarak toplumcu gerçekçi duygular aracılığıyla tasvir edilir. Dolayısıyla "biz" olma bilinci, aşkın ve onun oluşturduğu estetik endişelerin merkezinde, toplumcu gerçekçi bir bakışla birlikte ele alınır. Ortada hem kolektif bir endişe hem de bireysel bir aşk durumu söz konusudur. Sevgili salt şiir öznesinin duygu dünyasının coşkuları etrafında çizilmez. Aşk, sevgilinin içinde bulunduğu yaşam ve emek mücadelesi çerçevesinde ele alınır:

“şafaktan yıldızlara kadar fabrikadadır

hem ömrünü dokur hem yünlü dokur"

Burada dönemin çalışma ve iş düzenine karşı bir "isyan" vurgusunun var olduğu açıktır. Ancak önemli olan, şiirin terazisindeki aşk duygusuyla, isyan duygusunun arasındaki gel-git durumudur. Sözünü ettiğimiz isyan, yine sadece "düşünsel" ya da" ideolojik" bir zemine dayanmaz. Bu bakımdan, bir fabrika işçisi olan sevgilinin, "hem ömrünü hem de yünlüyü dokuması" fikri, şiirin estetik boyutları açısından da dikkat çekicidir. Burada tek başına "dokumak" kelimesi bile esasında şiirdeki estetik endişeyi imler. Ömrün ve yünlünün dokunması, madde ile özne arasındaki çatışmanın bir tezahürü olarak yorumlanabilir.

Şiirin devaminda ise sözünü ettiğimiz gel-git hâli sürdürülerek, perspektif yine toplumsal eleştiri düzlemine yönelir ve ayn sevgili, "yumulur yorgunluktan eve dönünce gözleri" ifadesiyle anlatılır. Ancak bu durum süreğen değildir ve şiirin birinci bölümündeki yaşama sevgisiyle ilgili dizelerin içerik olarak tekrar edilmesiyle birlikte iki bölüm arasında bağ kurulur. Dolayısıyla söz konusu tekrar, yine anlamsal olarak gel-git hâline hizmet eder. Kuşkusuz bu durum bizi şiirin yapısal özellikleri hakkında da düşünmeye itmektedir.

\section{DİL VE ÜSLUBUN DÜŞÜNDÜRDÜKLERİ}

Attilâ İlhan Duvar'ın dil ve üslup özelliklerinden bahsederken, "duvar'daki öz beraberliğinin yanı sıra, dikkati çeken bir deyiş ikiliğinin alt çizilebilir" (İlhan, 2008, s.12) şeklinde bir ifade kullanır. Kast edilen deyişteki bu ikilik durumunun yukarıda da görüldüğü üzere esasında şiirin hem içerik hem de dil ve üslup özelliklerinde kendini gösterdiğini yorumlamak mümkündür. Yapı açısından bu iddiaya örnek gösterilecek ilk husus, “İş Başı”nın kelime dağarcığıyla ilgilidir. Şiirde günlük sade ve anlaşılabilir 
kelimelerin kullanılmasının yanı sıra, "klâsik kültür" kaynağından gelen kelimelerin de kullanıldığı görülür. Örneğin müşterek, sema, mesut, pürheves, ahval-i sevda, meneviş gibi kelimelerin yanı sıra; fabrika, dokumak, yün, şarap, peynir ve ekmek gibi kelimelerin metinde bir arada yer aldığ1 görülmektedir. Bu bağlamda toplumcu gerçekçi kaygılarla estetik kaygıların bir arada sunuluşu, kelimelere dayalı bir gel-git hâliyle sağlanır. Bu tercihleri bir gel-git olarak yorumlamanın yanı sıra şairin, toplumcu gerçekçi şiirin söz varlığı içerisine Türk şiirinin klasikleşmiş edebî dili içerisinde yer alan "müşterek, sema, mesut, pürheves, ahval-i sevda, meneviş" gibi kelimelerin de girebileceğini göstermek isteğiyle açıklamak mümkündür. Dolayısıyla burada da kelimeleri seçiş ve kullanış tarzı bakımından toplumcu gerçekçi şiire karşıt bir duruş söz konusudur.

Şiirin dil özelliklerine genel olarak baktığımızda sade ve anlaşılır bir dil kullanımının tercih edildiğini görüyoruz. Ancak sözünü ettiğimiz gel-git hâlinin bir sonucu olarak, şiirin kimi dizelerinde klasik şiirin anlam dünyası ve ses özelliklerini çağrıştıran özelliklere rastlamak mümkündür. Şiirdeki, "kalbim

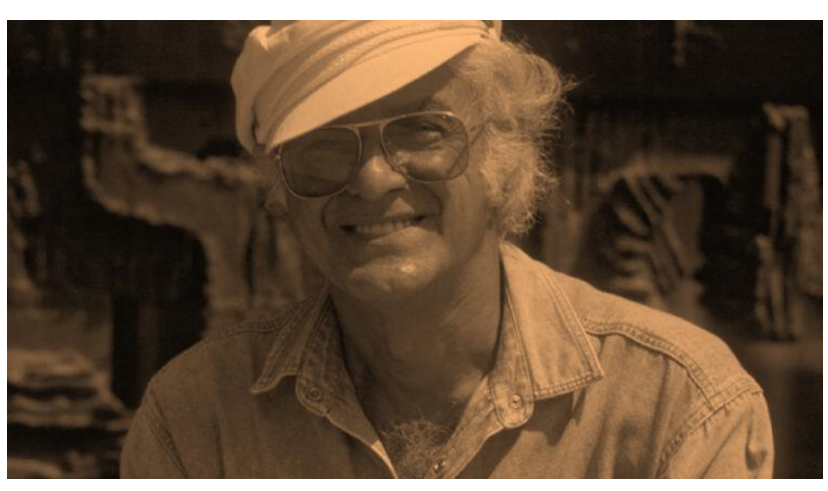

Attilâ İlhan

pürheves rüzgarda perişan saçlarım, kusura bakılmaz neyleyim ahval-ı sevdadır", dizeleri bu duruma örnek gösterilebilir. Bunun yanında, "benim bir sevgilim var gözleri menevişli, şafaktan yıldızlara kadar fabrikadadır" gibi dizelerde günlük bir dil kullanımı söz konusudur. Dolayıyla yukarıda, şiirin anlam düzleminde gördüğümüz "ikilik", dil ve üslup özellikleri açısından da kendini gösterir. Çünkü şiirde bu tip karşıtlıklara bağlı olarak hem romantik ve lirik söylem hem de açık ve gerçekçi bir söylemin var olduğu söylenebilir. Şüphesiz bu durumu sağlayan temel etmen, metnin anlam boyutunda gözlemlediğimiz tezat sanatının şiirin söylemi üzerindeki etkisidir. Dolayısıyla buradaki tezat sanatı, şiirde yaratılan duygulardaki ve söylemdeki gel-git durumunun somut bir göstergesidir.

"İş Başı"ndaki bazı edebi sanatlara baktığımızda ilk olarak, "kardeşlerim", "niçin" gibi kelimelerle başlayan dizlerde okuyucuya yönelik bir seslenişin dikkat çektiğini belirtmek gerekir. Bu durumu, toplumcu gerçekçi estetiğin "sesini duyurma", "eyleme davet etme" gibi söylemleriyle ilişkilendirmek mümkündür. Şiirin geneline ise benzetme sanatının hâkim olduğu gözlemlenmektedir. Örneğin daha önce sözünü ettiğimiz şarkının, sevinç ve ümit kavramlarına, çocuklar kahkahaya, ihtiyarlar tebessüme benzetilir. Bu benzetmede, yaşlılıkla gençlik arasındaki farklılıklar vurgulanır. En dikkat çekici benzetme ise, sevgilinin yorgun kuşlara benzetilmesidir. Bu noktada fabrikada ağır şartlarda çalışarak hayatını 
sürdüren sevgilinin yorgun kuşlara benzetilmesi, sözünü ettiğimiz sınıfsal sorunların estetik düzlemde ele alınış meselesini ifade eder.

Şiirleri zenginleştiren ögelerden biri de şüphesiz onlarda kurulan imgelerdir. "İş Başı" nın imge düzleminde de bir gel-git durumu söz konusudur. İmgelemdeki gel-git, şiirin hem içerik hem de dil ve üslup özelliklerinden kaynaklanır. Hatta bu özelliklerin bir araya gelmesinin şiirin imgesel yönünün temel özelliklerinden olduğu dahi söylenebilir. Örneğin toplumcu gerçekçi yaklaşımın bir sonucu olarak kolektif yaşamı imgeleştiren "kardeşim müşterek söylenir bir şarkımız vardır" dizesi aynı zamanda şiirin başlangıcıdır. Mutluluk düşüncesini ve yaşama sevincini imgeleyen, "ölüler mezarda tanrılar semada unutulur", “dünya günlük güneşlik insanlar sanki mesuttur” gibi dizeler, şiirin lirik yönünü ifade eder. Bütün bunların yanında, sözünü ettiğimiz şiirdeki gel-git hâlinin tek başına göstergesi olan ve yaşam mücadelesi içerisindeki aşkı imgeleştiren sevgili hakkındaki "yünlü dokur rüyasında ömrünü dokur" şeklindeki son dize, şiirin içerikten yapıya değin en dikkat çekici dizelerinden biridir. Burada ağır şartlar altında yün fabrikasında çalışan sevgilinin yaşam mücadelesiyle -aşk izleğinin bir sonucu olarak- onun rüyasında dokuduğu ömrü arasında etkili bir karşıtlık oluşturulur. "Yünlü dokumak" ve "rüya dokumak". Sonuçta şiirin gel-git hâlini “dokuyan" biraz da bu dizedir.

"İş Başı"nın anlatım özellikleri bakımından da yine bir "gelgit" hâlini yansıttığını ve bu durumun, şiirin etki gücünde önemli rol oynadığını söyleyebiliriz. Çünkü bu noktada anlatım açısından hem öyküleme hem de lirik anlatımın bir arada bulunduğu gözlemlenmektedir. Şiirde olayların ya da durumların kronolojik bir sırayla anlatılmasına öyküleyici anlatım denir. Burada mekân, kişi, zaman gibi ögeler öne çıkar (Yivli, 2013, s. 226). "İş Başı” ndaki özellikle şiir öznesiyle sevgili arasındaki ilişkinin sade bir anlatımla ele alındığı dizelerin, kısmen de olsa öyküleyici bir yapıda olduğunu söylemek mümkündür. Buna karşın özellikle aşk ve yaşama sevinci gibi temaların estetik boyutlarla ele alınması sonucunda lirik bir anlatımın da var olduğu söylenebilir. Çünkü burada, içten gelen bir duygulanma, coşkulu bir hâl söz konusudur. Özellikle toplumcu gerçekçi şiir anlayışına karşıt olarak, "niçin sade acıdan bahsetsin mısralarım" dizesiyle başlayan ve şiirin "bireysel" endişelerini yansıtan bölümlerde lirik anlatım özelliklerini gözlemlemek mümkündür.

\section{SONUÇ}

Sonuç olarak "İş Başı", toplumsal endişeyle, aşk izleğine dayalı bireysel endişenin terazisi üzerine kurulmuş bir şiirdir. Terazinin bir ucunda toplumcu gerçekçi poetikanın anlam dünyasında yer alan problemler, diğer ucunda ise şiir öznesinin kendi "ben" $i$ vardır. Bu durum, şiirde hem içerik hem de dil ve üslup özellikleri açısından bir "gel-git" durumu oluşmasına neden olmuştur. Bunu sağlayan poetik paradigmalar ise "İş Başı"nın anlamsal 
ve yapısal özellikleri açısından gözlemlenebilmektedir. İçerik olarak şiirin bir yönüyle, toplumcu gerçekçi bakış açısının ortak özelliklerinden olan iş, emek ve adaletsizlik gibi izlekler üzerine kurgulanan, diğer yönüyle ise bu endişeleri aşan ve şiir öznesinin kendi "ben"i ve duygu dünyası üzerine inşa edilen bir yapıda olduğu görülmektedir. Yapısal özellikler bakımından ise "İş Başı"nda, metni oluşturan kelime haznesi ve seçilen anlatım yöntemi açısından da bir gel-git durumu söz konusudur.

Bütün tespitlerin 1şığında, şairin bu şiiri üzerine ortaya koyduğumuz analizleri tümevarımsal olarak yorumlamak mümkündür. Attilâ İlhan'ın poetikasının çeşitli evrelerden oluştuğunu söylesek de esasında bu durumun eleştirel ölçütler açısından yeniden yorumlanabilir bir yapıda olduğunu belirtmemiz gerekir. Çünkü şairin yayımladı̆̆ı ilk şiir kitabı olan Duvar için kabul edilen poetik özelliklerin yanı sıra, "İş Başı" şiirinde farklı bir durum söz konusudur. "İş Başı”, yukarıda belitmiş olduğumuz özelliklerin bir sonucu olarak, şairin şiir serüveninde sadece farklı bir ses olarak kalmamış, bir bakıma kendinden sonra gelecek olan poetik endişe ve evrenin habercisi olmuştur. Bu bağlamda sözünü ettiğimiz "gel-git" durumu, geniş bir perspektiften bakacak olursak, esasında şairin poetik evreleri arasındaki gel-git durumunu da yansitmaktadır.

Attilâ İlhan"ın Duvar hakkındaki, "duvar, bir bakıma artık susmuş olan bir koronun şarkılarından bazı örnekler aktarıyor" (İlhan, 2008, s.11) şeklindeki sözlerine ortaya koyduğumuz tespitlerin ışığında tekrar bakmak gerekir. "İş Başı”, şairin sözünü ettiği "susma hâli" nden önce var olan, ancak kendinden sonra gelecek olan poetik evre için yeni bir "ses" olarak karşımıza çıkan bir şiirdir. Bu sesin toplumcu gerçekçi sanat anlayışı içerisinde kendini duyurmasını sağlayan temel sebeplerden biri ise poetik bir sorunsal olarak "geçiş" durumudur. Yapmış olduğumuz incelemeye bağlı olarak "İş Başı", şairin poetikasının ikinci ve üçüncü evrelerinden, izlek ve anlam dünyası açısından çeşitli izler taşır. Bu açıdan "İş Başı”"nın hem kendine özgü estetik nitelikleri hem de kendini aşan özellikleri itibarıyla Attilâ İlhan'ın poetikasındaki "geçiş" durumunun bir prototipi olduğu söylenebilir. Şairin toplumcu gerçekçi şiirin "kısıtlayıcı" sanat görüşünü aşmasını sağlayan durumlardan biri de tespit etmiş olduğumuz poetik geçiş durumudur. Poetik geçişin, onun sanatının statik olmaktan öte, dinamik bir özellik kazanmasını sağladığını söylemek mümkündür.

Sonuç olarak, şüphesiz Attilâ İlhan'ın diğer şiirleri üzerine yapılacak olan benzer okumalar, onun peoetikasındaki evrelerde görülen farklı geçiş durumlarını ölçümlemek açısından dikkate değer olacak, böylelikle şairin şiir anlayışındaki ileri ya da geriye dönük poetik geçiş örneklerinin tespit edilmesi mümkün olacaktır. 


\section{KAYNAKÇA}

Aristoteles (2018). Poetika. İstanbul: Can Yayınları.

Cengiz, Metin (2000). Toplumcu Gerçekçi Şiir. İstanbul: Tümzamanlar yayıncılık.

Cengiz, Metin (2005). Şiir, İmge, Biçim, Biçem (Şiirin Teorik Sorunları). İstanbul: Digraf Yayıncilık.

Cengiz, Metin (2005). Türk Şiirine Eleştirel Bir Bakış. İstanbul: Babil Yayınları.

Çelik, Yakup (2007). Şubat Yolcusu: Attilâ İlhan'ın Şiiri. Ankara: Akçă̆ Yay.

Çetin, Nurullah (2011). Şiir Çözümleme Yöntemi. Ankara: Öncü Kitap Yayınları.

Enginün, İnci (2005). Cumhuriyet Dönemi Türk Edebiyatı. İstanbul: Dergâh Yayınları.

İlhan, Attilâ (2004). İkinci Yeni Savaşı. İstanbul: İş Bankası Kültür Yayınları.

İlhan, Attilâ (2008). Duvar. İstanbul: Türkiye İş Bankası Kültür Yay.

İnce, Özdemir (1985). Şiir ve Gerçeklik. İstanbul: Broy Yayınları.

Kahraman, H. B. (2000). Türk Şiiri, Modernizm. Şiir. İstanbul: Büke Yayınları.

Korkmaz, Ramazan (2007). Yeni Türk Edebiyatı El Kitabı. Ankara: Grafiker Yayınları

Oktay, Ahmet (2008). Toplumcu Gerçekçiliğin Kaynakları. İstanbul: İthaki Yay.

Tunalı, İsmail (1993). Marksist Estetik. İstanbul: Altın Kitaplar Yayınevi.

Yivli, Oktay (2013). Metin Eloğlu'nun Şiiri. Ankara: Kurgan Edebiyat.

Yivli, Oktay (2019). “Cumhuriyet Dönemi Türk Şiiri”. Modern Türk Edebiyatı (2. basım). Ankara: Günce Yayınları. s. 265-319. 


\section{BATI EDEBIYATINDA AKIMLAR}

editör

OKTAY YIVLi

HATICE FIRAT YASEMIN MUMCU

OKTAY YIVLI

OĞUZHAN KARABURGU

BERNA AKYÜZ SIZGEN

NILÜFER ILHAN
ÜMMÜHAN TOPÇU

SEFA YÜCE

HANIFI ASLAN

METIN AKYÜZ

MEHMET SÜMER

YAKUP ÖZTÜRK
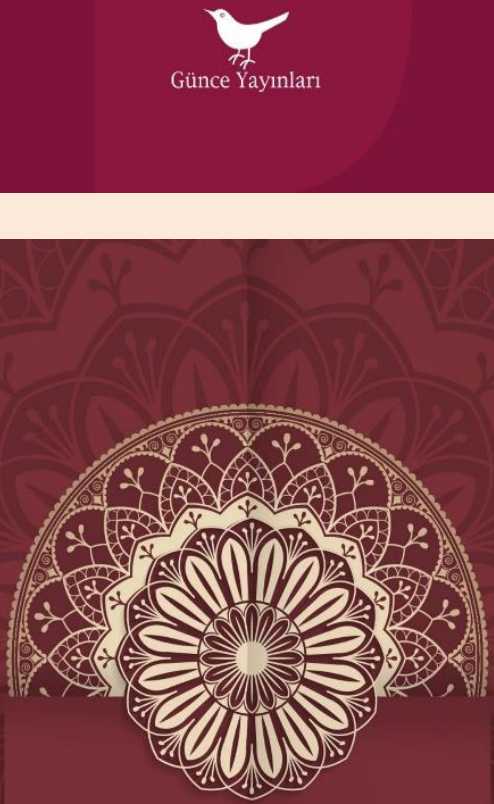

PROF. DR. ÖNDER GÖÇGÜN

$$
\begin{gathered}
\text { Türk } \\
\text { Tasavvuf } \\
\text { Siiri }
\end{gathered}
$$

AÇIKLAMALI VE YORUMLU ÖRNEKLERLE

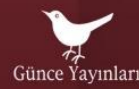

